\title{
Multi-organ damage by covid-19: congestive (cardio-pulmonary) heart failure, and blood-heart barrier leakage
}

\author{
Suresh C. Tyagi ${ }^{1} \cdot$ Mahavir Singh $^{1}$ (]
}

Received: 2 November 2020 / Accepted: 9 January 2021 / Published online: 22 January 2021

(c) The Author(s), under exclusive licence to Springer Science+Business Media, LLC part of Springer Nature 2021

\begin{abstract}
Corona virus disease-19 (covid-19) is caused by a coronavirus that is also known as severe acute respiratory syndrome coronavirus 2 (SARS-CoV-2), and is generally characterized by fever, respiratory inflammation, and multi-organ failure in susceptible hosts. One of the first things during inflammation is the response by acute phase proteins coupled with coagulation. The angiotensinogen (a substrate for hypertension) is one such acute phase protein and goes on to explain an association of covid-19 with that of angiotensin-converting enzyme-2 (ACE2, a metallopeptidase). Therefore, it is advisable to administer, and test the efficacy of specific blocker(s) of angiotensinogen such as siRNAs or antibodies to covid-19 subjects. Covid-19 activates neutrophils, macrophages, but decreases T-helper cells activity. The metalloproteinases promote the activation of these inflammatory immune cells, therefore; we surmise that doxycycline (a metalloproteinase inhibitor, and a safer antibiotic) would benefit the covid-19 subjects. Along these lines, an anti-acid has also been suggested for mitigation of the covid-19 complications. Interestingly, there are three primary vegetables (celery, carrot, and long-squash) which are alkaline in their pH-range as compared to many others. Hence, treatment with fresh juice (without any preservative) from these vegies or the antioxidants derived from purple carrot and cabbage together with appropriate anti-coagulants may also help prevent or lessen the detrimental effects of the covid-19 pathological outcomes. These suggested remedies might be included in the list of putative interventions that are currently being investigated towards mitigating the multi-organ damage by Covid-19 during the ongoing pandemic.
\end{abstract}

Keywords Connexin $\cdot$ Matrix metalloproteinases $\cdot$ Doxycycline $\cdot$ Endocardial endothelia $\cdot$ Fibrosis/remodeling

\section{Introduction}

Unfortunately, covid-19 related deaths in the Western hemisphere have already reached many thousands as compared to hundreds in the developing countries. This may, in part, be due to that hydroxychloroquine (HCQ) is being heavily prescribed to covid-19 patients as one of the treatments for covid-19 sickness. This review addresses that a low nontoxic dose of chloroquine (CQ) can benefit the patients against covid-19 (https://www.worldometers.info/coronaviru $\mathrm{s} /)[1,2]$. It is important to test the concept that complications by covid-19 or viral myocarditis such as congestive heart failure (CHF) can be mitigated by HCQ (a more potent derivative of CQ) (Fig. 1).

Mahavir Singh

mahavir.singh@louisville.edu; gene2genetics@gmail.com

1 Department of Physiology, University of Louisville School of Medicine, Louisville, KY 40202, USA
Several drugs have recently been either suggested or being clinically administered to relive the symptoms of covid-19. These include dapagliflozin (sodium glucose cotransporter 2; SGLT2 inhibitor; an antidiabetic), Lopinavir/ Ritonavir, Darunavir/Umifenovir (anti-HIV), Remdesivir (anti-Ebola), Favipiravir, and Dipyridamole (anti-hypertensive) [2-13]. Also, an anti-acid (Famotidine) is also being promoted [14]. Drugs like Famotidine (tradename; Pepcid) are histamine receptor antagonists that are routinely used to treat, and prevent certain types ulcers, and to treat conditions that cause the stomach to produce too much acid, and also to treat gastroesophageal reflux disease condition. Clinical evidence of the role of histamine in heart has been well documented, and histamine receptor antagonist in hypertension are cardioprotective [15-17]. Interestingly, HCQ is unique in the sense that, at low doses, it mitigates or blunts both the virus's direct effects, as well as the immune reaction/response. It is, therefore; important to employ a low dose HCQ to mitigate $\mathrm{CHF}$, and viral myocarditis-induced 


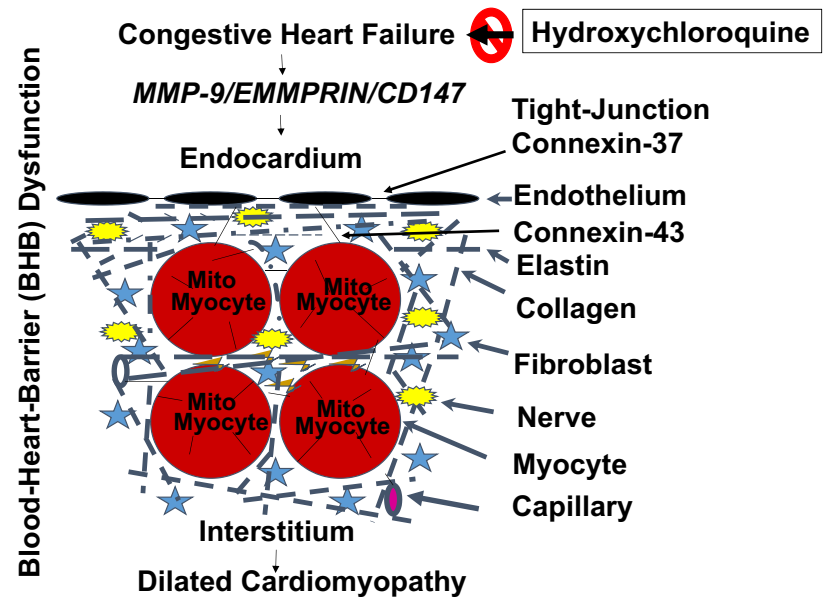

Fig. 1 HCQ, doxycycline, and the anti-acid mitigate CHF, and DCM, such as in aging, and viral myocarditis, caused by the chronic volume overload/preload. CHF instigates EE leakage and disrupts endothelial-endothelial, endothelial-myocyte, myocyte-myocyte and mitochondrial (Mito)-myocyte junctions. Activation of MMP-9 is the hallmark of CHF that disrupts connexin-37, and 43 leading to $\mathrm{EE}$ leakage, and DCM. HCQ, doxycycline, and anti-acid could help mitigate both CHF, and DCM. Abbreviations: HCQ; hydroxychloroquine, MMP-9; matrix metalloproteinase, EMMPRIN; extracellular matrix metalloproteinase inducer, CD-47; cluster of Differentiation 47

illness. In fact, a clinical study compared the suppressive effects of dipyridamole, and chloroquine on SARS-COV-2 replication, and suggested a similar titer at a concentration of just $100 \mathrm{nM}$ [3]. All this may suggest that this lower dose may be more effective clinically.

\section{Proteinase and covid-19}

An association of covid-19, and angiotensin-converting enzyme-2; ACE2 (a metallo-endopeptidase) has been put forward. Hence, covid-19 effects can possibly be mitigated by an inhibitor of metallo-enzymes. Because cardiac matrix is highly unique, and in that very context a cardio-specific matrix metalloproteinase (MMP) inhibitor may well suitably mitigate the blood-heart-barrier (BHB) leakage, and the subsequent dilated cardiomyopathy (DCM) phenotypes. We along this very line propose a cardiac-specific MMP inhibitor regulator (i.e. tissue inhibitor of metalloproteinase;TIMP) to reduce the chances of mortality that is related to covid-19 (Fig. 1).

HCQ intervention will be like the treatment with doxycycline; a suggested MMP inhibitor as reported in the prestigious journal; Nature Reviews for the purpose of tissue remodeling that reverses the endocardial endothelial (EE) dysfunction. Previously, we also demonstrated that an antibiotic mitigated matrix metalloproteinases (MMPs) activation during heart failure $[18,19]$. However, it is worth mentioning here that other common antibiotics such as azithromycin, clarithromycin, and erythromycin belonging to the 'macrolide' class have been shown to increase the risk of cardiac arrhythmias or even cardiac death [20]. Although, the use of broad-spectrum antibiotics as an antimicrobial therapy is a lifesaving strategy for patients in the intensive care but antibiotics also dramatically increase the risk for nosocomial infections, for example, the hospital-acquired pneumonia [21]. In a different context, it is unclear whether a salubrious effect arising from the use of a probiotic could also mitigate the MMPs' activation by covid-19. We showed by a 2-D zymography (that is MMPs' function and the proteome), the constitutive expression of MMP-2 in the control autopsy human heart sample; however, in the end-stage of the heart failure, the MMP-2, as well as, MMP-9 activities were found to be robust $[22,23]$. More recently, we went on to provide an evidence that a long-term probiotic treatment could help decrease the MMPs' activities [24] (Fig. 1). Further, nicotinamide, and mitochondria via SIRT mechanism regulate bioenergetics as demonstrated by us way back in 2002 , showing that nicotinamide did alleviate chronic heart failure syndrome [25]. A little later in 2004, our laboratory revealed that doxycycline could mitigate the deleterious implications between the endothelial- myocyte interaction(s) during the heart failure condition [19].

By now we are aware that the thromboembolic complications are responsible for morbidity and mortality among the susceptible covid-19 patients; however, the data also suggest a possible multifactorial basis of these complications. While every effort is being made by the medical experts to treat patients by taking suitable preventive measures employing anticoagulation therapeutics to deal with the coagulation issues. Despite superb benefits with the use of systemic anticoagulation therapies, the data seem to be retrospective in nature thus raising some questions on the possible interplay of other confounders, as well as, long-term benefits and safety of the systemic anticoagulation approach [26-34].

\section{Blood-heart-barrier (BHB) leakage}

The endothelium, whether it is in the endocardium or in coronary or capillaries, is the primary barrier against BHB dysfunction. The tight-junction proteins, viz., connexin-37 between endothelium and endothelium, connexin-43 between endothelium and myocyte, myocyte and myocyte, and mitochondria (mito) and myocyte are the primary connexins; however, it is important to determine the details of the events and mechanism(s) of BHB leakage during covid-19 infection, though. The juxtacrine endothelial-myocyte (E-M), myocyte-myocyte (M-M), and mitochondria (mito)-myocyte uncoupling(s) [23, 35-40] are the hallmarks of cardiac failure (Fig. 1). The role 
of connexin-43 which connects myocyte-myocyte, and mitochondria (mito)-myocyte should also be studied in the productive covid-19 infection scenario [41-43]. It is already known that the connexin-37 connects the endothelial and myocyte (E-M). In E-M, M-M, and mito-myocyte uncoupling(s), the role of MMP in degrading the connexins that are responsible for causing BHB dysfunction is unclear, as of today. Basement membrane between the endothelium, and muscle contains an extracellular matrix (ECM), latent MMPs/TIMPs/nitric oxide; NO (the ternary complex) (Fig. 1). However, oxidative stress during CHF activates MMPs, and inactivates the TIMPs via the peroxinitrite, and tyrosine/arginine nitosylation process [22].

The usage of antioxidants has been widely mentioned in the literature for their beneficial effects in chronic conditions because anthocyanins, phenolic acids, and carotenoids are the predominant phytochemicals that are present in purple carrots, and cabbage. Accordingly, they have been promoted in treatment of the metabolic syndromes because anthocyanins improve dyslipidemia, glucose tolerance, hypertension, and insulin resistance. Moreover, these phenolic acids may also protect against the cardiovascular diseases and, in fact. the $\beta$-carotene was shown to protect against the oxidative processes, as well $[44,45]$.

\section{Conclusion and perspective}

The role of HCQ in cardiac, and skeletal muscle remodeling is novel. The mitigation of systemic remodeling during CHF by HCQ is an innovative approach. The cardiac-specific MMP-9 can be inhibited by HCQ, and going by the foregoing discussion, it is therapeutically novel, including its potential clinical applications in the covid-19 patients (Fig. 1).

Acknowledgements The authors would like to thank all members of the laboratory for their continued help, and excellent support. Part of this study was supported by NIH Grants AR-71789, HL139047, and DK116591.

Author contributions MS and SCT conceived, wrote, edited, and finalized the manuscript while. The lab members helped in providing reagents, and the necessary feedback in moving forward this project. Authors approved the final version of the manuscript before its submission.

Funding A part of this work was supported by NIH Grants: AR-71789, HL139047, and DK116591.

\section{Compliance with ethical standards}

Conflict of interest The authors declare that they have no conflicts of interest.

\section{References}

1. Grasselli G, Zangrillo A, Zanella A, Antonelli M, Cabrini L, Castelli A, Cereda D, Coluccello A, Foti G, Fumagalli R, Iotti G, Latronico N, Lorini L, Merler S, Natalini G, Piatti A, Ranieri MV, Scandroglio AM, Storti E, Cecconi M, Pesenti A, Nailescu A, Corona A, Zangrillo A, Protti A, Albertin A, Forastieri Molinari A, Lombardo A, Pezzi A, Benini A, Scandroglio AM, Malara A, Castelli A, Coluccello A, Micucci A, Pesenti A, Sala A, Alborghetti A, Antonini B, Capra C, Troiano C, Roscitano C, Radrizzani D, Chiumello D, Coppini D, Guzzon D, Costantini E, Malpetti E, Zoia E, Catena E, Agosteo E, Barbara E, Beretta E, Boselli E, Storti E, Harizay F, Della Mura F, Lorini FL, Donato Sigurta F, Marino F, Mojoli F, Rasulo F, Grasselli G, Casella G, De Filippi G, Castelli G, Aldegheri G, Gallioli G, Lotti G, Albano G, Landoni G, Marino G, Vitale G, Battista Perego G, Evasi G, Citerio G, Foti G, Natalini G, Merli G, Sforzini I, Bianciardi L, Carnevale L, Grazioli L, Cabrini L, Guatteri L, Salvi L, Dei Poli M, Galletti M, Gemma M, Ranucci M, Riccio M, Borelli M, Zambon M, Subert M, Cecconi M, Mazzoni MG, Raimondi M, Panigada M, Belliato M, Bronzini N, Latronico N, Petrucci N, Belgiorno N, Tagliabue P, Cortellazzi P, Gnesin P, Grosso P, Gritti P, Perazzo P, Severgnini P, Ruggeri P, Sebastiano P, Covello RD, Fernandez-Olmos R, Fumagalli R, Keim R, Rona R, Valsecchi R, Cattaneo S, Colombo S, Cirri S, Bonazzi S, Greco S, Muttini S, Langer T, Alaimo V, Viola U (2020) Baseline characteristics and outcomes of 1591 Patients Infected With SARS-CoV-2 admitted to ICUs of the lombardy region, Italy. JAMA. https://doi. org/10.1001/jama.2020.5394

2. Borba MGS, Val FFA, Sampaio VS, Alexandre MAA, Melo GC, Brito M, Mourao MPG, Brito-Sousa JD, Baia-da-Silva D, Guerra MVF, Hajjar LA, Pinto RC, Balieiro AAS, Pacheco AGF, Santos JDO Jr, Naveca FG, Xavier MS, Siqueira AM, Schwarzbold A, Croda J, Nogueira ML, Romero GAS, Bassat Q, Fontes CJ, Albuquerque BC, Daniel-Ribeiro CT, Monteiro WM, Lacerda MVG (2020) Effect of high vs low doses of chloroquine diphosphate as adjunctive therapy for patients hospitalized with severe acute respiratory syndrome coronavirus 2 (sars-cov-2) infection: a randomized clinical trial. JAMA Netw Open 3:e208857. https://doi. org/10.1001/jamanetworkopen.2020.8857

3. Liu X, Li Z, Liu S, Sun J, Chen Z, Jiang M, Zhang Q, Wei Y, Wang X, Huang YY, Shi Y, Xu Y, Xian H, Bai F, Ou C, Xiong B, Lew AM, Cui J, Fang R, Huang H, Zhao J, Hong X, Zhang Y, Zhou F, Luo HB (2020) Potential therapeutic effects of dipyridamole in the severely ill patients with COVID-19. Acta Pharm Sin B. https://doi.org/10.1016/j.apsb.2020.04.008

4. Badyal DK, Mahajan R (2020) Chloroquine: can it be a novel drug for COVID-19. Int J Appl Basic Med Res 10:128-130. https://doi. org/10.4103/ijabmr.IJABMR_141_20

5. Hashem AM, Alghamdi BS, Algaissi AA, Alshehri FS, Bukhari A, Alfaleh MA, Memish ZA (2020) Therapeutic use of chloroquine and hydroxychloroquine in COVID-19 and other viral infections: A narrative review. Travel Med Infect Dis. https://doi. org/10.1016/j.tmaid.2020.101735

6. Klimke A, Hefner G, Will B, Voss U (2020) Hydroxychloroquine as an aerosol might markedly reduce and even prevent severe clinical symptoms after SARS-CoV-2 infection. Med Hypotheses 142:109783. https://doi.org/10.1016/j.mehy.2020.109783

7. Meo SA, Klonoff DC, Akram J (2020) Efficacy of chloroquine and hydroxychloroquine in the treatment of COVID-19. Eur Rev Med PharmacolSci 24:4539-4547. https://doi.org/10.26355/eurre v_202004_21038

8. Piszczatoski CR, Powell J (2020) Emergency approval of chloroquine and hydroxychloroquine for treatment of COVID-19. Ann Pharmacother. https://doi.org/10.1177/1060028020925558 
9. Shukla AM, Archibald LK, Shukla AW, Mehta HJ, Cherabuddi $\mathrm{K}$ (2020) Chloroquine and hydroxychloroquine in the context of COVID-19. Drugs Context. https://doi.org/10.7573/dic.2020-4-5

10. Taccone FS, Gorham J, Vincent JL (2020) Hydroxychloroquine in the management of critically ill patients with COVID-19: the need for an evidence base. Lancet Respir Med. https://doi.org/10.1016/ s2213-2600(20)30172-7

11. Docherty KF, Jhund PS, Inzucchi SE, Kober L, Kosiborod MN, Martinez FA, Ponikowski P, DeMets DL, Sabatine MS, Bengtsson O, Sjostrand M, Langkilde AM, Desai AS, Diez M, Howlett JG, Katova T, Ljungman CEA, O’Meara E, Petrie MC, Schou M, Verma S, Vinh PN, Solomon SD, McMurray JJV (2020) Effects of dapagliflozin in DAPA-HF according to background heart failure therapy. Eur Heart J. https://doi.org/10.1093/eurheartj/ehaa183

12. Costanzo M, De Giglio MAR, Roviello GN (2020) SARS-CoV-2: recent reports on antiviral therapies based on lopinavir/ritonavir, darunavir/umifenovir, hydroxychloroquine, remdesivir, favipiravir and other drugs for the treatment of the new coronavirus. Curr Med Chem. https://doi.org/10.2174/09298673276662004161 31117

13. Chiotos K, Hayes M, Kimberlin DW, Jones SB, James SH, Pinninti SG, Yarbrough A, Abzug MJ, MacBrayne CE, Soma VL, Dulek DE, Vora SB, Waghmare A, Wolf J, Olivero R, Grapentine S, Wattier RL, Bio L, Cross SJ, Dillman NO, Downes KJ, Timberlake K, Young J, Orscheln RC, Tamma PD, Schwenk HT, Zachariah P, Aldrich M, Goldman DL, Groves HE, Lamb GS, Tribble AC, Hersh AL, Thorell EA, Denison MR, Ratner AJ, Newland JG, Nakamura MM (2020) Multicenter initial guidance on use of antivirals for children with COVID-19/SARS-CoV-2. J Pediatric Infect Dis Soc. https://doi.org/10.1093/jpids/piaa045

14. Rogosnitzky M, Berkowitz E, Jadad AR (2020) Delivering benefits at speed through real-world repurposing of off-patent drugs: the COVID-19 pandemic as a case in point. JMIR Public Health Surveill 6:e19199. https://doi.org/10.2196/19199

15. Saheera S, Potnuri AG, Nair R (2017) Histamine-2 receptor antagonist famotidine modulates cardiac stem cell characteristics in hypertensive heart disease. PeerJ 5:e3882. https://doi.org/10.7717/ peerj.3882

16. Gergs U, Kirchhefer U, Bergmann F, Künstler B, Mißlinger N, Au B, Mahnkopf M, Wache H, Neumann J (2020) Characterization of stressed transgenic mice overexpressing $\mathrm{H}(2)$-histamine receptors in the heart. J PharmacolExpTher 374:479-488. https://doi. org/10.1124/jpet.120.000063

17. Kitakaze M (2016) Clinical evidence of the role of histamine in heart failure. J Am CollCardiol 67:1553-1555. https://doi. org/10.1016/j.jacc.2016.01.046

18. Hu J, Van den Steen PE, Sang QX, Opdenakker G (2007) Matrix metalloproteinase inhibitors as therapy for inflammatory and vascular diseases. Nat Rev Drug Discov 6:480-498. https://doi. org/10.1038/nrd2308

19. Camp TM, Tyagi SC, Aru GM, Hayden MR, Mehta JL, Tyagi SC (2004) Doxycycline ameliorates ischemic and border-zone remodeling and endothelial dysfunction after myocardial infarction in rats. J Heart Lung Transplant 23:729-736. https://doi. org/10.1016/j.healun.2003.06.005

20. Cheng YJ, Nie XY, Chen XM, Lin XX, Tang K, Zeng WT, Mei WY, Liu LJ, Long M, Yao FJ, Liu J, Liao XX, Du ZM, Dong YG, Ma H, Xiao HP, Wu SH (2015) The role of macrolide antibiotics in increasing cardiovascular risk. J Am CollCardiol 66:21732184. https://doi.org/10.1016/j.jacc.2015.09.029

21. Lohmeyer J, Morty RE, Herold S (2018) Antibiotic therapyinduced collateral damage: IgA takes center stage in pulmonary host defense. J Clin Invest 128:3234-3236. https://doi. org/10.1172/jci122032

22. Hunt MJ, Aru GM, Hayden MR, Moore CK, Hoit BD, Tyagi SC (2002) Induction of oxidative stress and disintegrin metalloproteinase in human heart end-stage failure. Am J Physiol Lung Cell MolPhysiol 283:L239-L245. https://doi. org/10.1152/ajplung.00001.2002

23. Brutsaert DL (2003) Cardiac endothelial-myocardial signaling: its role in cardiac growth, contractile performance, and rhythmicity. Physiol Rev 83:59-115. https://doi.org/10.1152/physr ev.00017.2002

24. George AK, Singh M, Pushpakumar S, Homme RP, Hardin SJ, Tyagi SC (2020) Dysbiotic 1-carbon metabolism in cardiac muscle remodeling. J Cell Physiol 235:2590-2598. https://doi. org/10.1002/jcp.29163

25. Cox MJ, Sood HS, Hunt MJ, Chandler D, Henegar JR, Aru GM, Tyagi SC (2002) Apoptosis in the left ventricle of chronic volume overload causes endocardial endothelial dysfunction in rats. Am J Physiol Heart CircPhysiol 282:H1197-H1205. https ://doi.org/10.1152/ajpheart.00483.2001

26. Ahmed SI, Khan S (2020) Coagulopathy and Plausible Benefits of Anticoagulation Among COVID-19 Patients. CurrProblCardiol 45:100648. https://doi.org/10.1016/j.cpcardiol.2020.10064 8

27. Al-Samkari H, Karp Leaf RS, Dzik WH, Carlson JCT, Fogerty AE, Waheed A, Goodarzi K, Bendapudi PK, Bornikova L, Gupta S, Leaf DE, Kuter DJ, Rosovsky RP (2020) COVID-19 and coagulation: bleeding and thrombotic manifestations of SARS-CoV-2 infection. Blood 136:489-500. https://doi.org/10.1182/blood .2020006520

28. Choudry FA, Hamshere SM, Rathod KS, Akhtar MM, Archbold RA, Guttmann OP, Woldman S, Jain AK, Knight CJ, Baumbach A, Mathur A, Jones DA (2020) High thrombus burden in patients with COVID-19 presenting with ST-segment elevation myocardial infarction. J Am CollCardiol 76:1168-1176. https://doi. org/10.1016/j.jacc.2020.07.022

29. Patti G, Lio V, Cavallari I, Gragnano F, Riva L, Calabrò P, Di Pasquale G, Pengo V, Rubboli A (2020) Antithrombotic treatments in patients with SARS-CoV-2 infection: from current evidence to reasonable recommendations - A position paper from the Italian Working Group on Atherosclerosis, Thrombosis and Vascular Biology. G ItalCardiol (Rome) 21:489-501. https://doi. org/10.1714/3386.33634

30. Sagardia LM, Daniels LM (2020) Thrombolysis and use of argatroban for the treatment of massive pulmonary embolism following anticoagulation failure in a patient with COVID-19. Am J Health Syst Pharm 77:1961-1964. https://doi.org/10.1093/ajhp/ zxaa287

31. Shah A, Donovan K, McHugh A, Pandey M, Aaron L, Bradbury CA, Stanworth SJ, Alikhan R, Von Kier S, Maher K, Curry N, Shapiro S, Rowland MJ, Thomas M, Mason R, Holland M, Holmes T, Ware M, Gurney S, McKechnie SR (2020) Thrombotic and haemorrhagic complications in critically ill patients with COVID19: a multicentre observational study. Crit Care 24:561. https:// doi.org/10.1186/s13054-020-03260-3

32. Sridharan GK, Vegunta R, Rokkam VRP, MeyyurAravamudan V, Vegunta R, Khan SR, Ponnada S, Boregowda U, Prudhvi K, Chamarthi G, Mohan BP (2020) Venous thromboembolism in hospitalized COVID-19 patients. Am J Ther 27:e599-e610. https ://doi.org/10.1097/mjt.0000000000001295

33. Watson RA, Johnson DM, Dharia RN (1995) Merli GJ and Doherty JU (2020) Anti-coagulant and anti-platelet therapy in the COVID-19 patient: a best practices quality initiative across a large health system. HospPract 48:169-179. https://doi. org/10.1080/21548331.2020.1772639

34. Wijaya I, Andhika R, Huang I (2020) The use of therapeuticdose anticoagulation and its effect on mortality in patients With COVID-19: A systematic review. ClinApplThrombHemost 26:1076029620960797. https://doi.org/10.1177/1076029620 960797 
35. Zima AV, Pabbidi MR, Lipsius SL, Blatter LA (2013) Effects of mitochondrial uncoupling on $\mathrm{Ca}(2+)$ signaling during excitationcontraction coupling in atrial myocytes. Am J Physiol Heart CircPhysiol 304:H983-H993. https://doi.org/10.1152/ajpheart.00932 .2012

36. Rodriguez WE, Sen U, Tyagi N, Kumar M, Carneal G, Aggrawal D, Newsome J, Tyagi SC (2008) PPAR gamma agonist normalizes glomerular filtration rate, tissue levels of homocysteine, and attenuates endothelial-myocyte uncoupling in alloxan induced diabetic mice. Int J BiolSci 4:236-244. https://doi.org/10.7150/ ijbs. 4.236

37. Sen U, Tyagi N, Moshal KS, Kartha GK, Rosenberger D, Henderson BC, Joshua IG, Tyagi SC (2007) Cardiac synchronous and dys-synchronous remodeling in diabetes mellitus. Antioxid Redox Signal 9:971-978. https://doi.org/10.1089/ars.2007.1597

38. Rosenberger D, Moshal KS, Kartha GK, Tyagi N, Sen U, Lominadze D, Maldonado C, Roberts AM, Tyagi SC (2006) Arrhythmia and neuronal/endothelial myocyte uncoupling in hyperhomocysteinemia. Arch PhysiolBiochem 112:219-227. https://doi. org/10.1080/13813450601093443

39. Mishra PK, Tyagi N, Sen U, Joshua IG, Tyagi SC (2010) Synergism in hyperhomocysteinemia and diabetes: role of PPAR gamma and tempol. CardiovascDiabetol 9:49. https://doi. org/10.1186/1475-2840-9-49

40. Tyagi SC, Rodriguez W, Patel AM, Roberts AM, Falcone JC, Passmore JC, Fleming JT, Joshua IG (2005) Hyperhomocysteinemic diabetic cardiomyopathy: oxidative stress, remodeling, and endothelial-myocyte uncoupling. J CardiovascPharmacolTher 10:1-10. https://doi.org/10.1177/107424840501000101
41. Givvimani S, Qipshidze N, Tyagi N, Mishra PK, Sen U, Tyagi SC (2011) Synergism between arrhythmia and hyperhomo-cysteinemia in structural heart disease. Int J PhysiolPathophysiolPharmacol 3:107-119

42. Tyagi N, Vacek JC, Givvimani S, Sen U, Tyagi SC (2010) Cardiac specific deletion of $\mathrm{N}$-methyl-d-aspartate receptor 1 ameliorates mtMMP-9 mediated autophagy/mitophagy in hyperhomocysteinemia. J Recept Signal Transduct Res 30:78-87. https://doi. org/10.3109/10799891003614808

43. Li H, Brodsky S, Kumari S, Valiunas V, Brink P, Kaide J, Nasjletti A, Goligorsky MS (2002) Paradoxical overexpression and translocation of connexin43 in homocysteine-treated endothelial cells. Am J Physiol Heart CircPhysiol 282:H2124-H2133. https ://doi.org/10.1152/ajpheart.01028.2001

44. Poudyal H, Panchal S, Brown L (2010) Comparison of purple carrot juice and $\beta$-carotene in a high-carbohydrate, high-fat diet-fed rat model of the metabolic syndrome. Br J Nutr 104:1322-1332. https://doi.org/10.1017/s0007114510002308

45. Miller HE, Rigelhof F, Marquart L, Prakash A, Kanter M (2000) Antioxidant content of whole grain breakfast cereals, fruits and vegetables. J Am CollNutr 19:312s-319s. https://doi. org/10.1080/07315724.2000.10718966

Publisher's Note Springer Nature remains neutral with regard to jurisdictional claims in published maps and institutional affiliations. 